This is a pre-print of the following article: L Series, 'Making sense of Cheshire West' in C Spivakovsky, L Steele and P Weller (eds) The Legacies of Institutionalisation: Disability, Law and Policy in the 'Deinstitutionalised' Community (Oñati International Series in Law and Society, Hart 2020).

\title{
MAKING SENSE OF CHESHIRE
} WEST

\section{LUCY SERIES}

Like many Western countries, the United Kingdom (UK) began its transition into what the socio-legal historian of mental health law, Clive Unsworth, terms the 'post-carceral era' ${ }^{1}$ in the mid-twentieth century. ${ }^{2}$ This era is characterised by policies and initiatives that seek to transplant populations of disabled people who might previously have been incarcerated in large institutions (long-stay hospitals, 'colonies', asylums and madhouses) into a mythical space called 'the community'.

The carceral era saw the proliferation of complex legal frameworks regulating institutional incarceration. Their function was to sort people into the locations where they 'correctly' belongedinstitution, or community-and to command public legitimacy through regulation of the internal workings of institutions (albeit not conditions the public themselves wished to inhabit). Under carceral-era logic, detention was synonymous with institutionalisation, and the community represented freedom. Accordingly, the legal status of populations now residing in the community changed: they were no longer 'detained'.

In the post-carceral era in England and Wales, a policy of 'informality' initially prevailed: the dismantling of complex carceral-era legislation, use of 'formal' detention apparatus only when hospital patients were actively resisting, and very limited use of formal legal frameworks governing compulsory treatment, coercion or control in the community. 'Informality' was necessary for the 'normalisation' of those being reintegrated into the community; 'legalism' hampered clinical discretion. ${ }^{4}$ Supervisory mechanisms like guardianship existed but were little used, and community treatment orders would not be implemented until after the turn of the millennium. ${ }^{5}$ However, by the late twentieth century 'legalism' was once again in the ascendant, resulting in significant reforms to mental health law ${ }^{6}$ and a statutory framework underpinning acts of care and treatment (in hospital or community) in the 'best interests' of persons lacking the 'mental capacity' to give or refuse consent: the Mental Capacity Act 2005 (MCA).

Six decades into the post-carceral era, the identification of community as 'freedom' is increasingly in doubt. There is ample evidence of residential care homes, and even settings espousing philosophies of 'independent living', failing to deliver on promises of choice and control, imposing restrictive

\footnotetext{
${ }^{1}$ C Unsworth, 'Mental Disorder and the Tutelary Relationship: From Pre- to Post-Carceral Legal Order' (1991) 18 Journal of Law and Society 2254.

${ }^{2}$ See especially Lord Percy, Report of the Royal Commission on the Law Relating to Mental IIIness and Mental Deficiency (Cm 169, 1957).

${ }^{3}$ See especially Mental Health Act 1959.

${ }^{4}$ B Hale et al, Mental Health Law (London, Sweet and Maxwell, 2017).

${ }^{5}$ P Fennell, 'Institutionalising the Community: The Codification of Clinical Authority and the Limits of RightsBased Approaches' in B McSherry and P Weller (eds), Rethinking Rights-Based Mental Health Laws (Oxford, Hart Publishing, 2010).

${ }^{6}$ Mental Health Act 1983.
} 
This is a pre-print of the following article: L Series, 'Making sense of Cheshire West' in C Spivakovsky, L Steele and P Weller (eds) The Legacies of Institutionalisation: Disability, Law and Policy in the 'Deinstitutionalised' Community (Oñati International Series in Law and Society, Hart 2020).

regimes, coercion, and sometimes abuse. ${ }^{7}$ A recent report on independent living in Europe concluded that institutional care had not been eradicated but rather 're-imagined': 'we face a proliferation of 'hidden' or 'mini' institutions. ${ }^{8}$

Twentieth-century de-carceration has been described as trans-incarceration, ${ }^{9}$ population shifts from one carceral space to another. Ben-Moshe cautions against oversimplifying this claim and calls for a more nuanced account of what gets coded as incarceration, recognising 'a continuum of carceral edifices. ${ }^{10}$ The overlapping properties Goffman identified in 'total institutions' may surface in a variety of ways and places, ${ }^{11}$ but this does not mean all carceral spaces are the same.

The question of what should be coded as incarceration has a legal analogue: what should we code as 'detention'? If 'community' is not synonymous with freedom, and if some practices in the community are strongly reminiscent of carceral-era institutions, under what circumstances should these be regulated as a form of detention?

\section{Coding 'Deprivation of Liberty'}

In England and Wales, we have been grappling with the meaning of 'deprivation of liberty' in postcarceral care settings for 15 years. Other countries and human rights bodies are also developing

\footnotetext{
${ }^{7}$ See eg Care Quality Commission, Learning Disability Services Inspection Programme: National Overview (2012) www.cqc.org.uk/sites/default/files/documents/cqc_ld_review_national_overview.pdf; C Drinkwater, 'Supported Living and the Production of Individuals' in S Tremain (ed), Foucault and the Government of Disability (Ann Arbor, University of Michigan Press, 2005); R Fyson, B Tarleton and L War, Support for Living? (York, Joseph Rowntree Foundation, 2007); Commission for Social Care Inspection and Healthcare Commission, Joint Investigation into the Provision of Services for People with Learning Disabilities at Cornwall Partnership NHS Trust (London, Commission for Healthcare Audit and Inspection, 2006) www.webarchive.nationalarchives.gov.uk/20080609161229/http://www.healthcarecommission.org.uk/_db/_ documents/cornwall_investigation_report.pdf

${ }^{8} \mathrm{~N}$ Crowther, 'The Right to Live Independently and to be Included in the Community in European States' (2019) European Network of Academic Experts in the Field of Disability www.disabilityeurope.net/theme/independent-living.

${ }^{9}$ eg J Lowman, R Menzies and T Palys, Transcarceration: Essays in the Sociology of Social Control (Avebury 1987).

${ }^{10} \mathrm{~L}$ Ben-Moshe, 'Disabling Incarceration: Connecting Disability to Divergent Confinements in the USA', (2013) 39 Critical Sociology 3, 385.

${ }^{11}$ E Goffman, Asylums: Essays on the Social Situation of Mental Patients and Other Inmates (New York, First Anchor, 1961).
} 
This is a pre-print of the following article: L Series, 'Making sense of Cheshire West' in C Spivakovsky, L Steele and P Weller (eds) The Legacies of Institutionalisation: Disability, Law and Policy in the 'Deinstitutionalised' Community (Oñati International Series in Law and Society, Hart 2020).

regulatory frameworks for detention in community settings. ${ }^{12}$ However, there is no internationally agreed definition of 'deprivation of liberty'. ${ }^{13}$

The question arose in England and Wales following the ruling of the European Court of Human Rights (ECtHR) in $H L v$ UK. ${ }^{14}$ An autistic man 'informally' admitted to Bournewood Hospital in his 'best interests' was found to have been unlawfully detained, notwithstanding that (in the view of the treating clinicians) he was not 'objecting' to his admission and had not attempted to leave. The MCA was subsequently amended to include 'deprivation of liberty safeguards' (DoLS), which apply in hospitals and care homes. ${ }^{15}$ The DoLS require, inter alia, independent assessments of a person's mental capacity and best interests, representation and independent advocacy, and access to the Court of Protection to review deprivation of liberty authorisations. The DoLS have been heavily (and justly) criticised ${ }^{16}$ and will soon be replaced by their successor-the Liberty Protection Safeguards. ${ }^{17}$ However, they provided a basic framework for scrutinising and challenging restrictive practices that hitherto was largely absent in residential community settings.

The Bournewood case triggered 10 long years of litigation on the meaning of 'deprivation of liberty', culminating in the UK Supreme Court decision in $P v$ Cheshire West and Chester Council and another; $P$ and $Q v$ Surrey County Council ${ }^{18}$ in 2014. The litigation concerned the ambit of Article 5 of the European Convention on Human Rights (ECHR), the right to liberty and security of the person. ECtHR jurisprudence identifies three limbs of deprivation of liberty: an 'objective' element of confinement in a 'certain limited space' for a non-negligible length of time; a 'subjective element' - the absence of valid consent to that confinement; and imputability to the state. ${ }^{19}$ The litigation leading up to

\footnotetext{
${ }^{12}$ eg W Boente, 'Some Continental European Perspectives on Safeguards in the Case of Deprivation of Liberty in Health and Social Care Settings' (2017) 23 International Journal of Mental Health and Capacity Law www.dx.doi.org/10.19164/ijmhcl.v2017i23.632; E Fritze, J Chesterman and P Grano, Designing a Deprivation of Liberty Authorisation and Regulation Framework (Melbourne, Office of the Public Advocate, Victoria, Australia, 2017); Victorian Law Reform Commission (VLRC), Guardianship Final Report Background Paper: Legislative Schemes Regulating Deprivation of Liberty in Residential Care Settings (Melbourne, VLRC, 2012); UNHRC, Report of the Special Rapporteur on the Rights of Persons with Disabilities, Catalina Devandas Aguilar (2019) A/HRC/40/54. See also: Complaints to the CRPD Committee DR v Australia (14/2003) 19 May 2017, CRPD/C/17/D/14/2013 and Jurisprudence of the European Court of Human Rights, eg Stanev v Bulgaria [2012] ECHR 46; DD v Lithuania [2012] ECHR 254. For detention monitoring, see reports from National Preventive Mechanisms to the UN Subcommittee on the Prevention of Torture from New Zealand, Norway, Austria, Croatia, Serbia, France (2012), The Netherlands, Poland, and Slovenia, www.ohchr.org/EN/HRBodies/OPCAT/Pages/AnnualreportsreceivedfromNPM.aspx.

${ }^{13}$ E Flynn, M Pinilla-Rocancio and M Gómez-Carrillo de Castro, 'Disability-Specific Forms of Deprivation of Liberty' (Centre for Disability Law and Policy, and Institute for Lifecourse and Society, NUI Galway, 2019) www.nuigalway.ie/media/centrefordisabilitylawandpolicy/files/DoL-Report-Final.pdfs.

${ }^{14}$ HL v UK [2004] ECHR 720.

${ }^{15}$ MCA Schedule A1, inserted via the Mental Health Act 2007.

${ }^{16}$ House of Lords Select Committee on the Mental Capacity Act 2005, Mental Capacity Act 2005: PostLegislative Scrutiny (HL Paper 139); Law Commission, Mental Capacity and Deprivation of Liberty (Law Com No $372,2017)$.

${ }^{17}$ New Schedule AA1, inserted into the MCA via the Mental Capacity (Amendment) Act 2019.

${ }^{18} P v$ Cheshire West and Chester Council and another; P and Q v Surrey County Council [2014] UKSC 19.

${ }^{19}$ Storck v Germany [2005] ECHR 406, at 74, 89.
} 
This is a pre-print of the following article: L Series, 'Making sense of Cheshire West' in C Spivakovsky, L Steele and P Weller (eds) The Legacies of Institutionalisation: Disability, Law and Policy in the 'Deinstitutionalised' Community (Oñati International Series in Law and Society, Hart 2020).

Cheshire West concerned only the 'objective element'; since 'mental capacity' was considered a necessary pre-requisite of valid consent it was taken to be missing in these cases. ${ }^{20}$

Several matters were at stake. The independent check required by Article 5 was increasingly attractive as confidence in other forms of care regulation collapsed. ${ }^{21}$ DoLS secured access to essential tools such as legal aid and advocacy to challenge care and treatment decisions under the MCA. ${ }^{22}$ A more expansive definition of deprivation of liberty captured growing recognition that restrictive practices occur widely in the community. However, there was (and is) ${ }^{23}$ resistance to the idea that 'benevolently' intentioned care, provided in the community, could amount to a deprivation of liberty. It threatens the post-carceral ideology of community as freedom.

\section{Cheshire West: The Facts}

The Supreme Court heard two conjoined cases. The first concerned two sisters with intellectual disabilities, MIG (aged 18) and MEG (aged 17). ${ }^{24}$ They were placed in foster care as teenagers because of a family background of sexual abuse and violence. MIG remained living with her foster mother. However, the placement with MEG's foster carer broke down, and she was moved to 'an NHS facility, not a care home, for learning disabled adolescents with complex needs. ${ }^{25}$

The second case concerned a 38-year-old man with cerebral palsy and Down syndrome referred to as ' $\mathrm{P}$ '. ${ }^{26} \mathrm{P}$ lived with his mother until he was 37 , when her health deteriorated. The council concluded she could no longer care for him and sought orders from the Court of Protection to move him into 'Z House'. Z House was not a care home, it was described as 'a spacious bungalow' with a 'pleasant atmosphere', near his family home and shared with two other residents. ${ }^{27}$

It is likely that Z House was 'supported living' accommodation. Under this service model, the resident is a tenant and receives 'domiciliary care'. As nominally private homes, these services are regulated differently to residential care ${ }^{28}$ and can have more generous funding and charging arrangements. The philosophy behind supported living is avowedly post-carceral: 'every person has the right to lead their own life-determine how they live, with whom they live, who provides them

\footnotetext{
${ }^{20}$ Cheshire West (UKSC) 55, 68.

${ }^{21}$ See especially R Francis, Report of the Mid Staffordshire NHS Foundation Trust Public Inquiry (HC 947, 2012).

${ }^{22}$ L Series, P Fennell and J Doughty, Welfare Cases in the Court of Protection: A Statistical Overview (Cardiff, Cardiff University, 2017) www.orca.cf.ac.uk/id/eprint/118054.

${ }^{23}$ E Flynn and M Gomez-Carrillo, 'Good practices to promote the right to liberty of persons with disabilities' (Galway, Centre for Disability Law and Policy and Institute for Lifecourse and Society, NUI Galway, 2019) www.nuigalway.ie/media/centrefordisabilitylawandpolicy/files/Good-practices-final-DoL.pdf.

${ }^{24}$ Surrey County Council v MEG \& MIG v Anor [2010] EWHC 785 (Fam) (henceforth: MIG and MEG (HC)); P \& Q $v$ Surrey County Council [2011] EWCA Civ 190 (henceforth: $P \& Q($ CoA)).

${ }^{25}$ Cheshire West (UKSC) 14.

${ }^{26}$ Cheshire West and Chester Council v P \& Anor [2011] EWHC 1330 (Fam) (henceforth: Cheshire West (HC)); Cheshire West and Chester Council v P [2011] EWCA Civ 1257 (henceforth: Cheshire West (CoA)).

${ }^{27}$ Cheshire West (UKSC) 17.

${ }^{28}$ Care Quality Commission, 'A New System of Registration. Supported Living Schemes' (no date) www.cqc.org.uk/file/4861.
} 
This is a pre-print of the following article: L Series, 'Making sense of Cheshire West' in C Spivakovsky, L Steele and P Weller (eds) The Legacies of Institutionalisation: Disability, Law and Policy in the 'Deinstitutionalised' Community (Oñati International Series in Law and Society, Hart 2020).

with help and support and how they live their lives. ${ }^{29}$ It mirrors the concept of 'independent living' encoded in Article 19 of the UN Convention on the Rights of Persons with Disabilities (CRPD). ${ }^{30}$ However, early pioneers of supported living later lamented that 'Too much of what goes today as Supported Living is relabelled Residential Care. ${ }^{31}$ Investors attracted to new revenue streams built 'clusters' of 'units', separate from mainstream housing, but found that financial viability competes with meaningful choice and control. ${ }^{32}$ Underlying supported living was a more fundamental problem: the reality was that often people were not making many critical decisions for themselves, others were making them on their behalf. ${ }^{33}$ Substitute decision-making is hard to square with philosophies of supported living.

MIG, MEG and P all engaged in regular activities that took them outside their accommodation. $P$ attended a day centre, hydrotherapy, saw his mother regularly, and went out (with one-to-one support) for pub lunches, to parks and garden centres. MIG and MEG attended college during the week and were described as having fairly active social lives. MIG also went on family holidays with her foster carer. Their lives did not fit the template of a person vanishing into a locked institution.

Yet the reality was that each was subject to varying degrees of supervision and control by their caregivers. The judgments-and perhaps the reality-blur the line between 'support' and control exercised by caregivers. MIG was described as 'largely dependent on others,' unable to 'go out on her own' and having 'no sense of safety and in particular no awareness of road safety. ${ }^{34}$ When not at the day centre she was 'under the control' of her foster mother or the council. ${ }^{35}$ However, MIG was not restrained or locked in. If she tried to leave the house on her own 'she would be restrained for her own immediate safety,' but she never had tried to leave or expressed any wish to do so. ${ }^{36}$

MEG and P's situations involved actual, rather than potential, restraint. Both received one-to-one or sometimes higher ratios of staff 'support' during their waking hours. MEG was described as having 'challenging behaviour' with 'outbursts' directed towards other residents, managed with restraint. ${ }^{37}$ This was said to be 'stabilising' thanks to 'behavioural management techniques' and the administration of risperidone to control her 'anxiety'. ${ }^{38}$ Despite growing concern about

\footnotetext{
${ }^{29}$ P Kinsella, 'Supported Living: The Changing Paradigm - from Control to Freedom' (2001) www.familyadvocacy.com/assets/Uploads/Downloadables/11288-Supported-Living-The-Changing-Paradigm.pdf. ${ }^{30}$ United Nations, Convention on the Rights of Persons with Disabilities (adopted 13 December 2006, entered into force 3 May 2008) 2515 UNTS 3 (CRPD).

${ }^{31}$ P Kinsella, 'Supported Living - Fact or Fiction?' (2008). No longer available online; copy archived by author.

${ }^{32}$ W Laing, Homecare and Supported Living: UK Market Report (Laing \& Buisson, 2018); Voluntary Organisations Disability Group and Anthony Collins Solicitors, 'When is a Care Home not a Care Home?' (2011) www.vodg.org.uk/wp-content/uploads/2011-VODG-When-is-a-care-home-not-a-care-home-briefing.pdf.

33 J Mansell, 'The 'Implementation Gap' in Supported Accommodation for People with Intellectual Disabilities' in T Clement and C Bigby (eds), Group Homes for People with Intellectual Disabilities (London, Jessica Kingsley, 2009).

${ }^{34}$ MIG and MEG (HC), 208, 210.

35 ibid, 211.

36 ibid, 210.

37 ibid, 215.

38 ibid, 215-6.
} 
This is a pre-print of the following article: L Series, 'Making sense of Cheshire West' in C Spivakovsky, L Steele and P Weller (eds) The Legacies of Institutionalisation: Disability, Law and Policy in the 'Deinstitutionalised' Community (Oñati International Series in Law and Society, Hart 2020).

overmedication and restraint of people with intellectual disabilities, ${ }^{39}$ neither the specific nature of the restraint nor the effects of risperidone on MEG were explored in detail in court. ${ }^{40}$

The local authority had a 'no restraint' policy and staff at Z House had no restraint training, yet P's arrangements involved a considerable degree of physical intervention. Like MEG, $P$ was described as presenting 'challenging behaviour': stripping off his clothes, throwing things, self-harming, smearing faeces and occasionally 'pulling, pinching, grabbing and scratching' others. He also had continence problems. When living with his mother he had been 'allowed' to be naked, but in Z House he wore continence pads, which he would tear and sometimes put into his mouth. This choking risk had required hospital admissions. ${ }^{41}$ Staff tried to reduce risk factors, for example through regular bathroom visits reducing the need for pads, verbal redirection and positive reinforcement, but 'sometimes had to resort to physical intervention' when P had 'stored' pieces of a pad or faecal material in his mouth. They would insert their fingers into his mouth to check for and remove material, hold P's hand to clean it, and change his pad and clothes. P would 'attempt to fight against staff during these interventions. ${ }^{42} \mathrm{~A}$ new approach of $\mathrm{P}$ wearing a 'bodysuit' prevented access to the pads.

Despite graphic descriptions of 'challenging behaviour' and caregivers' benevolent intentions, descriptions of claimants' subjective experiences of their living arrangements are scant and sometimes contradictory. None of the three chose their place of residence. MIG and MEG were described as not wishing to leave their homes, not wishing to live with their mother, and having no 'capacity to conceptualise any alternative unfamiliar environment. ${ }^{43}$ Yet only MIG was described as having positive feelings about her situation: 'She does not wish to leave. She wants to stay with JW. She loves JW and regards JW as her "Mummy". ${ }^{44}$ At trial MEG was described as wanting 'to remain living in her present environment', ${ }^{45}$ but the Supreme Court judgment describes her as mourning the loss of the relationship with her foster carer and wishing she was still living with her. ${ }^{46}$ The discrepancy between these accounts is not explored. Her 'outbursts' towards other residents suggest she may not have been happy living with them. The Court of Appeal acknowledged that 'antipsychotic drugs and other tranquilisers' might suppress potential objections, but nowhere analysed whether this was the case for MEG. ${ }^{47}$

We glean even less information about $\mathrm{P}^{\prime} \mathrm{s}$ wishes and feelings from the judgments. An independent social worker flagged the need for a specialist communication profile and suggested his 'challenging behaviour' could be a method of communication. ${ }^{48} \mathrm{He}$ is described as 'sociable' with other residents

\footnotetext{
${ }^{39}$ eg Care Quality Commission, 'Interim Report: Review of Restraint, Prolonged Seclusion and Segregation for People with a Mental Health Problem, a Learning Disability and or Autism' (2019) www.cqc.org.uk/publications/themed-work/interim-report-review-restraint-prolonged-seclusion-segregationpeople.

${ }^{40}$ MIG and MEG (HC), 216.

${ }^{41}$ Cheshire West $(\mathrm{HC})$ 8, 13.

${ }^{42}$ Cheshire West $(\mathrm{HC}) 9$.

${ }^{43}$ MIG and MEG (HC), 225.

44 ibid, 209.

45 ibid, 224.

${ }^{46}$ Cheshire West (UKSC), 14.

${ }^{47}$ MIG and MEG (CoA) 26.

${ }^{48}$ Cheshire West (HC) 7, 11.
} 
This is a pre-print of the following article: L Series, 'Making sense of Cheshire West' in C Spivakovsky, L Steele and P Weller (eds) The Legacies of Institutionalisation: Disability, Law and Policy in the 'Deinstitutionalised' Community (Oñati International Series in Law and Society, Hart 2020).

and enjoying 'going out into the community. ${ }^{49}$ No force, threats or subterfuge were involved in his move into $Z$ House.

\section{Were MIG, MEG or P Deprived of Liberty?}

The cases proceeded on separate but intersecting tracks through trial and appeals. Each of the claimants was represented by a litigation friend, the Official Solicitor, who argued they were deprived of their liberty.

Mrs Justice Parker found MIG and MEG had not been deprived of their liberty. Their situations were, she concluded, very far from the 'paradigm' of imprisonment. ${ }^{50}$ She had not met MIG and MEG but concluded their 'wishes and feelings are manifest and clearly expressed. They plainly have no subjective sense of confinement.' She suggested that, 'In a non legal sense they have the capacity to consent to their placements.' She had not visited their placements, but concluded no visitor 'would gain any sense of confinement or detention. ${ }^{51}$ Parker J placed considerable emphasis on the purpose (safety) and intentions (benevolent) of MIG and MEG's caregivers. She held that 'Each lacks freedom and autonomy dictated by their own disability, rather than because it is imposed on them by their carers. ${ }^{52}$ The Official Solicitor appealed. In the Court of Appeal, Lord Justice Wilson concluded that any benevolent purpose was irrelevant to the objective analysis of whether a person was deprived of their liberty (but would be relevant to whether it was justified). ${ }^{53}$ Wilson $\mathrm{L}$ identified two dimensions for the assessment of whether a person is 'objectively' deprived of their liberty: the 'relative normality' of their situation, and whether or not they 'object'. ${ }^{54}$ There was a 'wide spectrum' of how 'normal' a person's living arrangements could be. At one end was 'the most normal life possible' - a person living with their natural family; 'not much less normal' was life with a foster carer. At the other end of the spectrum were institutions designed for compulsory detention, like Bournewood Hospital, where HL was detained, with small children's homes or nursing homes falling in between. ${ }^{55}$ The enquiry into 'normality' also considered activities and occupations such as attending college or a day centre, and outside social contact. ${ }^{56}$ However, Wilson L's enquiry into 'relative normality' did not consider other trappings of institutional life central to contemporary deinstitutionalisation campaigns: restraint, regimes of supervision and control, choice over where and with whom one lives, and from whom one receives support.

The second limb, objections, was relevant to the objective element of deprivation of liberty because it could lead to 'conflict', arguments, the stress of objections overruled, perhaps even 'tussles', restraint and forcible returns to confinement. Meanwhile, the absence of objections 'generates an absence of conflict and thus a peaceful life,' pointing away from a deprivation of liberty. ${ }^{57}$ Sedating

\footnotetext{
${ }^{49}$ Cheshire West (HC) 7, 11, 54.

${ }^{50}$ MIG and MEG (HC) 235.

51 ibid, 234.

52 ibid, 233.

${ }^{53}$ MIG and MEG (CoA) 27.

54 ibid, 25, 28.

55 ibid, 28.

56 ibid, 29.

57 ibid, 25.
} 
This is a pre-print of the following article: L Series, 'Making sense of Cheshire West' in C Spivakovsky, L Steele and P Weller (eds) The Legacies of Institutionalisation: Disability, Law and Policy in the 'Deinstitutionalised' Community (Oñati International Series in Law and Society, Hart 2020).

or tranquilising medication potentially suppressed objections and was thereby relevant to the enquiry. ${ }^{58}$

It was plain that MIG's situation did not satisfy either limb of this analysis, but puzzling that MEG's situation was held not to either. MEG's life in an 'NHS facility' did involve 'tussles', with some suggestion of objections overruled or potentially suppressed via medication.

P's case subsequently came to trial. Mr Justice Baker applied Wilson L's framework for 'relative normality'. He observed that the council and Z House 'have taken very great care to ensure that P's life is as normal as possible', ${ }^{59}$ he did not live in accommodation designed for compulsory detention, had regular contact with his family, enjoyed a 'good social life' and went on outings. However, Baker $\mathrm{J}$ concluded that $\mathrm{P}$ was deprived of his liberty because

his life is completely under the control of members of staff at $Z$ House. He cannot go anywhere or do anything without their support and assistance. More specifically, his occasionally aggressive behaviour, and his worrying habit of touching and eating his continence pads, require a range of measures, including at times physical restraint, and, when necessary, the intrusive procedure of inserting fingers into his mouth whilst he is being restrained. ${ }^{60}$

The council appealed. On appeal, Lord Justice Munby revisited Wilson LJ's analysis of 'relative normality'. Baker J had applied the wrong test, he concluded, by comparing P's life to 'the life of the able-bodied man or woman on the Clapham omnibus. ${ }^{61}$ The correct comparator for the analysis of 'relative normality' was instead 'the kind of lives that people like X would normally expect to lead,' an adult or child of similar age, similar 'capabilities' and affected by the same condition. ${ }^{62}$ Applying this analysis, Munby $L J$ ruled that $P$ was not deprived of his liberty. Further, Munby $\amalg$ resurrected Parker J's consideration of benevolent reasons for the restrictions as a factor pointing away from an objective deprivation of liberty.

Matters were, however, 'very different' if a person 'has somewhere else to go and wants to live there' but is prevented from doing so 'by a coercive exercise of public authority. ${ }^{63}$ This catered to situations like HL, or like Steven Neary-a man who was unlawfully deprived of his liberty in a 'positive behaviour unit', whom the court ruled could return to live in his own home with support from his father and a team of personal assistants. ${ }^{64}$

On Munby LJ's analysis, a person with 'nowhere else to go' would need to demonstrate that their life was abnormally more restrictive than others with a similar disability to qualify for detention safeguards. In C v Blackburn and Darwen Borough Council, ${ }^{65}$ this approach meant that even a man who had broken down the door of a care home trying to escape was not deprived of his liberty

\footnotetext{
58 ibid, 26, 37.

${ }^{59}$ Cheshire West $(\mathrm{HC}), 58$.

60 Ibid, 59.

${ }^{61}$ Cheshire West (CoA) 87.

62 Ibid, 97.

63 Ibid, 58.

${ }^{64}$ London Borough of Hillingdon v Neary [2011] EWHC 1377 (COP).

${ }^{65}$ C v Blackburn and Darwen Borough Council [2011] EWHC 3321 (COP).
} 
This is a pre-print of the following article: L Series, 'Making sense of Cheshire West' in C Spivakovsky, L Steele and P Weller (eds) The Legacies of Institutionalisation: Disability, Law and Policy in the 'Deinstitutionalised' Community (Oñati International Series in Law and Society, Hart 2020).

because he had nowhere else to go. Meanwhile, in CC $v$ KK and STCC, ${ }^{66}$ a woman in a care home who wished to return to her own home was found not to be deprived of her liberty because although she was 'objecting' this no longer led to a 'significant degree of conflict,' and the care home was far removed from 'the type of institution associated with a deprivation of liberty' in Wilson LJ's spectrum. ${ }^{67}$ She was not deprived of her liberty.

As commentators observed, the comparator approach rests on a medical model of disability that locates restrictions on liberty within the person, not their environment. ${ }^{68}$ It imposed a discriminatory hurdle for disabled people to claim the protection of Article 5 ECHR. Together with consideration of the 'reasons' for any restrictions, it was hard to see how a person could both be deprived of their liberty and for it to be lawful under the DoLS. ${ }^{69}$ The number of DoLS applications, already lower than government projections, fell for the first time. ${ }^{70}$ The Official Solicitor appealed.

Seven justices heard the conjoined appeals to the Supreme Court. Lady Hale delivered the leading judgment. She prefaced her analysis by observing that if a person were not found to be deprived of their liberty then 'no independent check' is made on whether their care arrangements were in their best interests. ${ }^{71}$ Munby U's 'comparator' approach was rejected by all seven justices, Lady Hale observing that 'The whole point about human rights is their universal character,' and citing the UN CRPD. ${ }^{72}$ Applying what she took to be the ratio in $\mathrm{HL}$ and subsequent cases before the ECtHR, ${ }^{73}$ Lady Hale held that the 'acid test' of deprivation of liberty is whether a person is subject to continuous supervision and control and not free to leave. ${ }^{74}$ That they are not objecting, that the arrangements are the least restrictive possible, that their living arrangements are as 'comfortable' or their life as 'enjoyable' as it could be, is irrelevant to the objective question of whether they are deprived of their liberty: 'A gilded cage is still a cage. ${ }^{75}$

Three justices concurred with Lady Hale's analysis, and three dissented; thus, by a slim majority, the 'acid test' remains the primary test of whether a person is deprived of their liberty by their care arrangements under UK law. Lords Carnwath and Hodge were concerned that this went further than the European Court of Human Rights: there was no precedent for a 'universal test', however attractive. ${ }^{76}$ They argued that 'nobody using ordinary language would describe people living happily

${ }^{66}$ CC v KK [2012] EWHC 2136 (COP).

${ }^{67}$ ibid 99, 101.

${ }^{68}$ B Clough, “"People Like That": Realising the Social Model in Mental Capacity Jurisprudence' (2015) 23 Medical Law Review 1, 53.

${ }^{69}$ B Troke, 'The Death of Deprivation of Liberty Safeguards?' (2012) 3 Social Care and Neurodisability 2, 56.

${ }^{70}$ The judgment was handed down on 9 November 2011. See falling quarterly rates of DoLS applications after this point in Table 2 of Health and Social Care Information Centre, 'Mental Capacity Act 2005, Deprivation of Liberty Safeguards Assessments, England - 2012-13, Annual Report' (2013) 11 www.digital.nhs.uk/data-andinformation/publications/statistical/mental-capacity-act-2005-deprivation-of-liberty-safeguardsassessments/mental-capacity-act-2005-deprivation-of-liberty-safeguards-assessments-england-2012-13annual-report.

${ }^{71}$ Cheshire West (UKSC) 1.

${ }^{72}$ Cheshire West (UKSC) 36.

${ }^{73}$ Stanev v Bulgaria; DD v Lithuania; Kędzior v Poland [2012] ECHR 1809; Mihailovs v Latvia [2013] ECHR 65.

${ }^{74}$ Cheshire West (UKSC) 48-49.

${ }^{75}$ Cheshire West (UKSC) 46.

${ }^{76}$ Cheshire West (UKSC) 94. 
This is a pre-print of the following article: L Series, 'Making sense of Cheshire West' in C Spivakovsky, L Steele and P Weller (eds) The Legacies of Institutionalisation: Disability, Law and Policy in the 'Deinstitutionalised' Community (Oñati International Series in Law and Society, Hart 2020).

in a domestic setting as being deprived of their liberty. ${ }^{, 77}$ They were concerned that such a test could now apply to HL, living at home with the carers who had fought to liberate him from Bournewood Hospital. ${ }^{78}$

\section{Deprivation of Liberty in the Post-Carceral Era}

The Cheshire West 'acid test' shatters the institution/community binary underpinning both carceral and post-carceral-era ideologies of care, identifying that elements of supervision, control and loss of freedom exist outside of traditional institutions. This resonates with insights from critical disability studies. ${ }^{79}$ A similar working model of deprivation of liberty was recently employed in a major study of disability-related detention. ${ }^{80}$ The 'acid test' is attractive for those seeking to call out restrictive practices and coercion wherever they appear, and challenge post-carceral mythology.

Whilst noting these attractions-and confirming that I too initially greeted the Supreme Court's judgment with enthusiasm - I must sound a note of caution on the Cheshire West model. The Supreme Court was, undoubtedly, right to reject analyses of deprivation of liberty that infantilised and discriminated against disabled people, which found that 'benevolent' purpose rendered coercion free of scrutiny, that attributed loss of autonomy to impairment, not environment, that was based on a fantasy life of freedom in the home and community. However, the consequences of Cheshire West have been very significant, and not all are necessarily conducive to addressing legitimate concerns about carceral practices in post-carceral settings.

Following Cheshire West, an estimated 300,000 people are considered deprived of their liberty in connection with their care arrangements in England and Wales, including one in every 16 people aged over $85 .{ }^{81}$ This exceeds the number of psychiatric detentions at the end of the carceral era. To cope with this increase in volume, the DoLS were replaced with more flexible but ultimately much weaker safeguards against arbitrary detention: ${ }^{82}$ the trade-off with volume may be decreased protection of rights.

Cheshire West did not contest the legitimacy of the kinds of 'supervision and control' exercised over disabled people in post-carceral settings, it merely held that they must be regulated using the machinery of Article 5 ECHR. Neil Allen-an academic and barrister for Cheshire West and Chester Council in the litigation-argues that there is a risk that 'the law ends up cementing the care relationship to a prison paradigm. ${ }^{83}$

\footnotetext{
${ }^{77}$ Cheshire West (UKSC) 99, see also Lord Clarke 108.

${ }^{78}$ Cheshire West (UKSC) 99. NB: As an adult, HL would not have 'foster parents'. His living arrangements resemble 'shared lives' schemes in which adults live in private homes with families who provide care and support.

${ }^{79}$ L Ben-Moshe, C Chapman and AC Carey (eds), Disability Incarcerated: Imprisonment and Disability in the United States and America (New York, Palgrave Macmillan, 2014).

${ }^{80}$ Flynn, Pinilla-Rocancio and Gómez-Carrillo de Castro, 'Disability-Specific Forms of Deprivation of Liberty' (2019).

${ }^{81}$ Department of Health and Social Care, 'Impact Assessment: Mental Capacity (Amendment) Bill' (2019) www.services.parliament.uk/Bills/2017-19/mentalcapacityamendment/documents.html.

82 Mental Capacity (Amendment) Act 2019.

${ }^{83}$ N Allen, 'The (Not So) Great Confinement', (2015) 5 Elder Law Journal 1, 45, 46.
} 
This is a pre-print of the following article: L Series, 'Making sense of Cheshire West' in C Spivakovsky, L Steele and P Weller (eds) The Legacies of Institutionalisation: Disability, Law and Policy in the 'Deinstitutionalised' Community (Oñati International Series in Law and Society, Hart 2020).

One might respond that Cheshire West should act as a spur to eradicate such practices. The 'independent check' cited by Lady Hale may indeed address some restrictive practices on a case-bycase basis; however, this will operate within the menu of options available within an austeritystricken and marketised landscape of adult social care. It will not make better options available. And, as Foucauldian scholars have observed, regulation can have paradoxical effects: 'by purporting to exercise its supervisory jurisdiction only over the more egregious aberrations, abuses and excesses of disciplinary power, law confirms the basic claim at the heart of disciplinary power. ${ }^{84}$

The Cheshire West case is hard to reconcile to the CRPD. Doubtless, all disability human rights advocates agree that the definition of deprivation of liberty must not discriminate against disabled people. Article 14 CRPD confirms disabled people are entitled to equal due process guarantees, with reasonable accommodation, yet it also states that 'the existence of a disability shall in no case justify a deprivation of liberty.' If indeed MIG, MEG and P are deprived of their liberty, we must ask whether there is any lawful justification for it under the CRPD.

In considering this question, we must take considerable care to ask what is being justified here. Is it measures to prevent, for example, MIG from wandering in front of road traffic, or P from choking on an incontinence pad? I struggle to imagine any human rights advocate arguing that the CRPD prevents this. Yet we must be careful to distinguish interventions to prevent real, imminent and serious risks from their wider living arrangements. We might, for example, agree that interventions to prevent MEG attacking others could be justified (as they would be for any non-disabled person), but look at what is triggering this behaviour, and explore other facets of her living arrangements, including behaviourism-inspired regimes and use of sedating medication. We might agree that $P$ should not be left to choke, but want to determine how he feels about the rest of his living arrangements.

One of the underlying problems with the 'acid test' is that it (deliberately) excludes consideration of the person's subjective experiences. This has the result of collapsing together the situation of someone like MIG, who appears to be positively happy with her living arrangements, and someone like MEG, where there are reasonable grounds to suspect she may not be. Following Cheshire West, the council that had unlawfully detained Steven Neary applied to the Court of Protection for authorisation of deprivation of liberty in his own home. ${ }^{85}$ The processes to 'authorise' this was reportedly distressing for Neary. The council's assessors ultimately concluded that he was happy where he was (nonetheless, still detained).$^{86}$ The point is not only that in some cases the authorisation process itself may carry a cost for the person, but that by continuing to label a person as 'detained' when they are expressing a positive desire to live as they are, including the support they receive, this invalidates the person's own expressed wishes. It reinforces the very binary model of 'mental capacity' that the CRPD is said to repudiate. ${ }^{87}$

\footnotetext{
${ }^{84}$ B Golder and P Fitzpatrick, Foucault's Law (London, Routledge-Cavendish, 2009) 66.

85 Joint Committee on Human Rights, The Right to Freedom and Safety: Reform of the Deprivation of Liberty

Safeguards (HC 890, HL paper 161, 2018) [38].

${ }^{86} \mathrm{M}$ Neary, 'Silly DoLS Talking' Love, Belief and Balls (2018)

www.markneary1dotcom1.wordpress.com/2018/06/09/silly-dols-talking/.

${ }^{87}$ CRPD Committee, 'General comment No 1 (2014) Article 12: Equal recognition before the law' (2014) UN

Doc CRPD/C/GC/1, 2014.
} 
This is a pre-print of the following article: L Series, 'Making sense of Cheshire West' in C Spivakovsky, L Steele and P Weller (eds) The Legacies of Institutionalisation: Disability, Law and Policy in the 'Deinstitutionalised' Community (Oñati International Series in Law and Society, Hart 2020).

One option, therefore, is to deepen our consideration of the subjective element of deprivation of liberty, and expand our horizons of what constitutes a valid consent to any element of 'supervision and control'. This was recently proposed by English barrister and academic Alex Ruck Keene ${ }^{88}$ and endorsed by the Parliamentary Joint Committee on Human Rights. ${ }^{89}$ An amendment to the MCA was tabled, proposing that a person should be considered to have given a 'valid consent' to a potential deprivation of liberty if they are 'capable of expressing their wishes and feelings (verbally or otherwise),' they had expressed 'their persistent contentment' with the arrangements, there was 'no coercion involved' in their implementation, and this was confirmed in writing by two professionals (one independent of the person's care). ${ }^{90}$ Despite potentially dramatically reducing the administrative difficulties posed by Cheshire West, this approach was rejected by the government on the basis that it conflicted with the position under the ECHR. ${ }^{11}$ The idea that a 'mentally incapable' person could give a valid consent was unthinkable.

There are, undoubtedly, risks to the 'valid consent' approach. The judiciary in the Cheshire West litigation was content to describe even MEG as validly consenting in a 'non legal sense' and as 'happy' in her accommodation, despite strong pointers to the contrary. ${ }^{92}$ There is a risk that compliance by those who do not use conventional methods of communication, who are sedated, scared or institutionalised, may be constructed as 'consent'. There is equally a risk that potential pointers that a person is unhappy may be pathologised and dismissed as 'challenging behaviour'. But surely the appropriate response is to engage with these risks head on through directly confronting these tropes and developing a better jurisprudential and cultural engagement with the subjective experiences of people with mental disabilities?

Based on the reported facts, the 'valid consent' approach would appear to identify MIG and Steven Neary as not detained, because they are expressing positive contentment (as opposed to not objecting) to their living arrangements, and no direct coercion is used. MEG and P would still be considered detained, owing to uncertainty over their feelings and the use of coercion. This leaves us with the hard question of whether such measures can ever be justified under the CRPD, a question lying well beyond the scope of this chapter. The difficulty is that we are still trying to fit the binary machinery of detention regulation to a complex matrix of practices, which include intervention to protect against real, immediate and serious risks (eg, choking) but extend well beyond this. What appears to be needed is an entirely new regulatory structure for the post-carceral age. It may well be that the CRPD is better placed to assist in its development than older paradigms still rooted in carceral ideology, but we have not found it yet.

\footnotetext{
${ }^{88}$ A Ruck Keene, 'Discussion Paper: Deprivation of Liberty, Cheshire West and the CRPD' (39 Essex Chambers, 2017) www.39essex.com/wp-content/uploads/2017/12/Valid-Consent-Discussion-Paper-December2017.docx.pdf.

89 Joint Committee on Human Rights, Legislative Scrutiny: Mental Capacity (Amendment) Bill (HC 1662 HL 208, 2018).

90 ibid, 12-13.

${ }^{91} \mathrm{HL}$ Deb, 21 November 2018 vol 794 col 252 (Lord O'Shaughnessy).

92 MIG and MEG (HC), 24; P \& Q (CoA) 24; Cheshire West (UKSC) 99, 108.
} 
This is a pre-print of the following article: L Series, 'Making sense of Cheshire West' in C Spivakovsky, L Steele and P Weller (eds) The Legacies of Institutionalisation: Disability, Law and Policy in the 'Deinstitutionalised' Community (Oñati International Series in Law and Society, Hart 2020).

\section{Acknowledgments}

This research was funded by the Wellcome Trust as part of a Society and Ethics Research Fellowship, grant number 200381/Z/15/Z.

Grateful thanks to all authors in this volume and the editors for their helpful feedback on this chapter, and for our generous hosts at Oñati for the workshop. 